\title{
Impact of Political Instability on Foreign Direct Investment in Lebanon
}

\author{
Nicholas Bitar ${ }^{1}$, Mohamad Hamadeh ${ }^{1} \&$ Roy Khoueiri ${ }^{1}$ \\ ${ }^{1}$ Notre Dame University, Louaize \\ Correspondence: Nicholas Bitar. E-mail: nbitar@ndu.edu.lb
}

Received: October 28, 2019

Accepted: November 10, 2019 Online Published: December 31, 2019

doi:10.5539/ass.v16n1p41

URL: https://doi.org/10.5539/ass.v16n1p41

\begin{abstract}
Foreign direct investment (FDI) is an important determinant of economic growth. A wealth of literature has tackled its determinants; however few investigated the effect of political risk on FDI. Consequently, this study examines 12 ICRG political risk indicators, after removing multicollinearity and grouping them into three categories, to test the nature of this relation in the case of Lebanon over the period 2008-2018. The findings provide evidence of significant causality between all political risk factors and FDI inflows. Other determinants like "Infrastructure", "Inflation", "Trade Openness" and "Wage Rates" have insignificant effects.
\end{abstract}

Keywords: FDI, political risk, economic growth, governance, quality of Institutions, Lebanon, trade openness, infrastructure, inflation, wage rates

\section{Introduction}

Foreign direct investment (FDI) inflows play an integral role in stimulating economic growth. More to the point, FDI inflows enhance the transfer of technology, productivity of domestic firms and financial capital needs, thereby generating job opportunities and therefore leading to economic growth. Countries in the MENA region have not been doing well in benefiting from the aforementioned advantages as compared to developed countries, and the region is still lagging behind because of the dragging conflicts and the regional wars. Political unrest leads to uncertainties that have the effect of forgoing investment opportunities, thus impeding economic growth.

Howell (2001) views political risk as "political and social events in a country that affect the business climate in such a way that investors will lose money or not make as much money as they expected". Husain (2009) notes that a beneficial business environment relies heavily on political stability in a country. The probable downturn of business activities could result from political risk that comes from change in governments, change in legislative bodies and military control. From this perspective, Root (1994) provides a detailed analysis, concluding that the success of any contractual business arrangement is systematically related to the transition of political constraints. Moreover, Khan and Akbar (2013) argue that uncertainty in the economic environment is directly related to political instability, which in turn negatively affects the foreign investors' decisions.

The objective of this research is to investigate the blurred relation between instability and FDI inflows. The limitation in the number of studies is largely attributed to the lack of available FDI data in the MENA region, which hinders the ability of researchers to reach a consensus on the determinants of FDI inflows.

With a total population of around five million and unemployment rate as high as $34 \%$, Lebanon, one of the dragging MENA countries, fails to attract foreign investors. According to the World Investment Report published by UNCTAD, while total FDI inflows in the developing countries grew from 419 billion USD in 2007 to 706 billion USD in 2018, they declined in Lebanon from 3.2 billion USD to 2.8 billion USD over the same period. The decline is attributed mainly to the political instability and the deterioration of the economy resulting from regional wars. In this respect, Lebanon is still enduring until today the political, social, and economic consequences of the war in Syria, internal political instability where the country witnessed a presidential vacuum from 2014 until 2016, after which the country was unable to form a government for around 8 months. All of those factors contribute to the further hindering of investors' confidence in the country, therefore justifying the importance of researching and scrutinizing the determinants of FDI. Consequently, a question may arise as the trigger behind this research; namely, what are the determinants of FDI in Lebanon and what are the political risk factors that influence them?

The following section provides a discussion of the available literature on the topic as well as the theoretical 
framework used to explain the determinants of FDI with an emphasis to the MENA region. The third section introduces the methodology used, the correlation between the political risk indicators, and the effect of the macroeconomic and of the institutional determinants on FDI inflows, followed by the analysis of the main results from the empirical findings and the conclusion.

\section{Review of Literature}

Several studies were conducted on developed and developing countries, testing the effect of economic, financial and political factors on FDI. Some authors support the "grabbing hand" theory, whereby political instability adds transaction cost of foreign investment as investors are forced to pay bribes in order to facilitate their business. Political instability adds another layer of uncertainty on economic activity, thereby disrupting production and reducing foreign investors incentives to invest in a country. Al-Khouri and Abdul Khalik (2013) argue that institutional quality and political stability along with stable macroeconomic policies are essential elements in catching the attention of foreign investors. Furthermore, Sparks et al. (2014) state that there are five areas that determine foreign direct investment, and the second most important ones after the economic factors are the political factors. Moreover, Gastanga et al. (1998) contend that countries with unreliable legal system and high corruption receive less FDI.

Other authors support the "helping hand" theory, which argues for a positive relationship between political instability and FDI, especially when then risk is associated with corruption. Corruption allows businesses to jump legal protocols and expensive paperwork. Egger and Winner (2005) and Dreher and Gassebener (2013) claim that corruption reduces bureaucratic hurdles and overcomes governmental complicated procedures of doing business, thereby facilitating the procedures of starting and doing business.

The empirical relationship between political stability and FDI inflows was investigated by several scholars. Asif et al. (2018) used ARDL model to show that government stability and low external conflict encourage FDI in the Long run in Pakistan. Abdul Kahlik and Masih (2017) employed Autoregressive distributed lag (ARDL) approach to co-integration to find that there is a long run and short run relationship between political instability and FDI. Kurecic and Kokotovic (2017) employed Granger Causality test and Vector Autoregressive framework (VAR) to find a long term relation between political instability and FDI for a panel of small economies, but no such relationship was found for larger economies. In addition, Sobia (2015) used Granger multivariate causality study to find that regime durability and FDI have bidirectional long term causal relation in Pakistan.

Goswami and Haider (2014) used data of 146 developed and developing countries between 1984 and 2009. Political stability was proxied by the 12 ICRG political risk indicators, which were grouped into three categories by using factor analysis. After eliminating multicollinearity between the political risk components, they ran a regression using pooled OLS and the fixed-effect approach. They found that market size, economic growth, openness to trade, and infrastructure have positive effects, while cultural conflict and partners' attitude showed negative relations with FDI. Governance failure showed inconsistent results.

Khan and Akbar (2013) tackled the relationship between political risk and FDI while emphasizing on each political risk factor by using panel data of 94 countries over the period 1986-2009. They tested their data on the whole world, lower middle income countries, upper middle income countries, low income countries, and high income countries. They reached a consensus that no matter the region or the country, nations should work on mitigating political risk and uncertainty because they affect FDI negatively, and their role is integral in the determination of FDI inflows.

Al-Khouri and Abdul Khalik (2013) studied the effect of the political risk factor on FDI net inflows in the MENA region. Taking all countries together, the results showed that aggregate political risk, as expected, has proven to be negatively related with FDI, and among the 12 political risk indicators, corruption and external conflict showed a statistically significant negative relation with FDI, whereas less democracy and more socioeconomic pressures showed statistically significant and positive relation with FDI.

Furthermore, Hayakawa et al. (2012) used the risk indices of ICRG supplied by the PRS group to tackle the effect of a mixture of political and financial risk components (namely country risk) on FDI inflows for the period 1985-2007. They considered a sample of 93 developed and developing countries, while focusing more on the latter by considering 60 developing countries. They used the fixed effects models and the dynamic GMM methodology to run their regressions. Hayakawa et al. (2012) concluded that political risk is a robust determinant of FDI, and among the 12 ICRG components, they found that socioeconomic conditions, internal and external conflict, government stability, religious tensions, corruption, investment profile, ethnic tensions, and democratic accountability are important determinants of FDI flows. Specifically, investment profile, external conflict, and socioeconomic conditions were the most influential among the components. On the other hand, the financial risk 
index turned out to be insignificant.

Lee and Rajan (2011) investigated trends and patterns of FDI data flows for the period 2000-2005, including bilateral FDI flows to and from Asia-Pacific Economic Cooperation (APEC) countries, taking intra-APEC net FDI flows into consideration and using an amplified gravity model framework to run their regression. They took a sample of 16 APEC countries out of the 21 economies and found that countries with minor country risk political, economic, or financial - appear to be a magnet for more FDI inflows. The higher effect on FDI originates from political risk as opposed to financial risk or economic risk, which turned out to be insignificant when taken separately from political risk.

Slangen and Beugelsdijk (2010) studied the effect of institutional hazards on vertical and horizontal FDI. In particular, the researchers explained the two forms of institutional hazards that reduce FDI, which are informal cultural distance and formal governmental deficiency; the former concerns differences between countries in negotiations styles and communication, managerial and organizational practices, effective marketing techniques, desired behaviors, and customer preferences, whereas the latter concerns the quality of the governance system in the country and its deficiency means higher political instability and higher chance of sudden changes of policies like taxes, quotas, and nationalization. The researchers tested their hypotheses in a contingency framework for the period 1996-2004 by using data on aggregate sales of merchandises by US foreign affiliates that are present in various host countries. They used generalized least squares regression, seemingly unrelated regression, and Heckman's two-stage. The results show that institutional hazards have a more negative and significant effect on vertical FDI, and governance deficiencies have a more negative and significant effect than cultural distance on both forms of FDI.

Furthermore, the study of Sekkat and Veganzones-Varoudakis (2007) tackled the entire investment environment in a country, which concerns the location advantages in the OLI paradigm, and includes infrastructure endowment, economic environment, and political environment. The researchers studied the effect on total FDI flows and on FDI in manufacturing using a panel data econometric regression model - fixed and random effects -for the period 1990-1999. The sample used for total FDI consisted of 72 developing countries, while the sample for FDI in manufacturing only consisted of 20 observations due to the lack of data. The results for total FDI showed that market size, openness, infrastructure, economic risk, and political risk are significant and positively related to FDI.

Busse and Hefeker (2007) used OLS, fixed effect and generalized method of moments on 83 developing countries for the period 1984-2003, where each factor from the 12 International Country Risk Guide (ICRG) components was added and regressed, along with other control variables, to find the impact on FDI. They conclude that political risk and institutions indicators are highly significant with FDI and highly important for investment decisions of multinational corporations (MNEs).

Blanton and Blanton (2007) used the two-stage-least-square approach on a group of developing countries for the period 1980-2003 to demonstrate that enhanced human rights leads to higher FDI. Harms and Ursprung (2002) used panel estimation and cross-sectional regression applied on 62 emerging markets between 1989 and 1997 to find that civil and political repression's indices negatively affect FDI.

Few studies found a positive relationship between political risk (corruption, in particular) and FDI. Omodero (2019) found that corruption has a positive impact on FDI in Nigeria. Similarly, Gutierrez (2015) employed OLS to find a positive relationship between the two variables in Argentina. Egger and Winner (2005) used paned data from 73 developed and less developed countries to find that corruption is a clear stimulus of FDI.

\section{Methodology}

This research examines the determinants of FDI inflows in Lebanon for the period 2008 till 2018. The study considers a set of macroeconomic variables and political risk indicators as independent variables, and FDI inflows as the dependent variable.

The model uses the political risk index taken from the International Country Risk Guide (ICRG) that is provided by the PRS group to find the adverse effect of political risk on FDI inflows. The PRS group supplies 12 risk indicators that tackle different components of political risk. To include them all in the same regression leads to massive multicollinearity, which jeopardizes the robustness of the results.

The need for the Factor Analysis technique is necessary, given the large number of factors and the high multicollinearity they bring in a single regression. In addition, the 12 different indicators introduced by ICRG cover most of the aspects of political risk available in the literature. The Principal Component Factor Analysis technique is used to condense the 12 ICRG into a smaller set of highly correlated factors that reflect the more 
general dimensions.

Once factor analysis reveals a new set of components, OLS technique is then used to estimate the following:

FDI $=\beta_{0}+\beta_{1}$ GROWTH $+\beta_{2}$ OPENNESS $+\beta_{3}$ INFRA $+\beta_{4}$ INFLATION $+\beta_{5}$ LABOR $+\beta_{\mathrm{i}}$ PR $_{\mathrm{i}}+\varepsilon$, where:

- $\quad$ FDI is foreign direct investment measured in millions of USD.

GROWTH: Economic growth, growth rate of real GDP.

OPENNESS: Trade openness, the ratio of the sum of imports and exports to GDP.

INFRA: Infrastructure, proxied by the quarterly average of the number of hours of electricity supplied per day.

INFLATION: Quarterly inflation rate.

LABOR: Labor cost, provided by the minimum wage rate in Lebanese Lira

- $\quad$ PR: Political risk, proxied by a vector of political risk variables.

- $\quad$ E: Error term

Following the literature, the expected signs of the estimated coefficients are positive for $\beta_{1}, \beta_{2}, \beta_{3}$, and $\beta_{\mathrm{i}}$, and negative for $\beta_{4}$, and $\beta_{5}$.

Quarterly data covering the years 2008 until 2018 is collected from Banque Du Liban (FDI, GDP, Imports and Exports), from Electricite Du Liban (infrastructure), from IMF (CPI), from Central Administration for Statistics (CAS) (minimum wage), and from Political Risk Services group (political risk factors).

\section{Findings}

Table 1 shows that the mean of each indicator varies between a low score (reflecting higher risk) and a middle score (moderate risk). In fact, the mean of "Bureaucracy Quality", "Law and Order", "Corruption", "Military in Politics", and "Religious Tensions" is remarkably low (below 4) implying that political risk in Lebanon is high corresponding to these. On the other hand, the mean of "Democratic Accountability", "Ethnic Tensions", "Internal Conflict", "External Conflict", "Socioeconomic Conditions", "Investment Profile", and "Government Stability" show a moderate risk (between 4 and 8). Also, Lebanon's lowest risk is found in "Government Stability", "Internal Conflict", "External Conflict", and "Investment Profile" due to relatively high mean values compared to the other indicators.

Table 1. Descriptive Analysis of the Political Risk Indicators

\begin{tabular}{cccccc}
\hline & Observations & Mean & SD & Min. & Max. \\
\hline Bureaucracy Quality (L) & 44 & 1.8 & 0.32 & 1 & 2 \\
Corruption (F) & 44 & 1.6 & 0.36 & 1 & 2 \\
Democratic Accountability (K) & 44 & 3.6 & 0.68 & 3 & 5 \\
Ethnic Tensions (J) & 44 & 5.4 & 0.45 & 5 & 6 \\
External Conflict (E) & 44 & 7.0 & 0.14 & 7 & 7.5 \\
Government Stability (A) & 44 & 6.4 & 0.85 & 5.5 & 8.3 \\
Internal Conflict (D) & 44 & 6.1 & 0.83 & 5 & 7.7 \\
Investment Profile (C) & 44 & 7.5 & 0.94 & 6 & 8.5 \\
Law \& Order (I) & 44 & 3.9 & 0.60 & 3 & 4.5 \\
Military in Politics (G) & 44 & 2.4 & 0.35 & 2 & 3 \\
Religious Tensions (H) & 44 & 2.7 & 0.25 & 2.5 & 3 \\
Socioeconomic Conditions (B) & 44 & 5.1 & 0.28 & 5 & 6 \\
\hline
\end{tabular}

Table 2.a shows that the correlation level is significant for most indicators, with the exception of "Corruption" with "Bureaucracy Quality", "Investment Profile", "Internal Conflict, and "Government Stability". In addition, Table 2.b reveals that a high correlation exists between different political risk indicators. For example, "Bureaucracy Quality", "Internal Conflict", "Law and Order" and "Religious Tensions" are highly correlated with pairwise coefficients of correlation exceeding 0.8 . 
Table 2.a: Significance level Correlation Matrix

\begin{tabular}{|c|c|c|c|c|c|c|c|c|c|c|c|c|}
\hline & $\mathrm{L}$ & $\mathrm{F}$ & $\mathrm{K}$ & $\mathrm{J}$ & $\mathrm{E}$ & A & $\mathrm{D}$ & $\mathrm{C}$ & I & G & $\mathrm{H}$ & B \\
\hline $\mathrm{L}$ & & • & & & & & & & & & & \\
\hline F & .120 & & & & & & & & & & & \\
\hline K & .000 & .002 & & & & & & & & & & \\
\hline $\mathbf{J}$ & .000 & .035 & .000 & & & & & & & & & \\
\hline $\mathrm{E}$ & .037 & .000 & .000 & .011 & & & & & & & & \\
\hline A & .002 & .243 & .000 & .000 & .009 & & & & & & & \\
\hline D & .000 & .105 & .000 & .000 & .013 & .000 & & & & & & \\
\hline $\mathrm{C}$ & .000 & .466 & .000 & .000 & .007 & .000 & .000 & & & & & \\
\hline I & .000 & .065 & .000 & .000 & .010 & .000 & .000 & .000 & & & & \\
\hline G & .086 & .096 & .000 & .016 & .003 & .000 & .002 & .000 & .00 & & & \\
\hline $\mathrm{H}$ & .000 & .052 & .000 & .000 & .016 & .001 & .000 & .000 & .000 & .041 & & \\
\hline B & .011 & .037 & .000 & .001 & .000 & .000 & .002 & .001 & .001 & .000 & .003 & \\
\hline
\end{tabular}

Table 2.b. Coefficient Correlation Matrix

\begin{tabular}{|c|c|c|c|c|c|c|c|c|c|c|c|c|c|}
\hline & & $\mathrm{L}$ & $\mathrm{F}$ & $\mathrm{K}$ & $\mathrm{J}$ & $\mathrm{E}$ & A & $\mathrm{D}$ & $\mathrm{C}$ & I & $\mathrm{G}$ & $\mathrm{H}$ & B \\
\hline \multirow[t]{12}{*}{592} & $\mathrm{~L}$ & 1.000 & & & & & & & & & & & \\
\hline & $\mathrm{F}$ & -.181 & 1.000 & & & & & & & & & & \\
\hline & $\mathrm{K}$ & .646 & -.418 & 1.000 & & & & & & & & & \\
\hline & $\mathrm{J}$ & -.873 & .276 & -.821 & 1.000 & & & & & & & & \\
\hline & $\mathrm{E}$ & .272 & -.573 & .543 & -.345 & 1.000 & & & & & & & \\
\hline & A & .424 & -.108 & .489 & -.480 & .353 & 1.000 & & & & & & \\
\hline & $\mathrm{D}$ & .815 & -.193 & .836 & -.915 & .335 & .643 & 1.000 & . & & & & \\
\hline & $\mathrm{C}$ & .618 & -.013 & .653 & -.613 & .369 & .769 & .745 & 1.000 & & & & \\
\hline & I & .829 & -.231 & .720 & -.880 & .349 & .554 & .835 & .736 & 1.000 & & & \\
\hline & $\mathrm{G}$ & -.209 & .201 & -.575 & .373 & -.414 & -.612 & -.430 & -.654 & -.474 & 1.000 & & \\
\hline & $\mathrm{H}$ & .855 & .249 & -.772 & .931 & -.325 & -.472 & -.891 & -.575 & .803 & .265 & 1.000 & \\
\hline & B & .345 & -.273 & .671 & -.438 & .615 & .498 & .457 & .469 & .443 & -.525 & -.412 & 1.000 \\
\hline
\end{tabular}

Using the Scree plot, Figure 1 shows that after the third factor, the Eigenvalues drop below 1, which means that the 12 political risk indicators are condensed into 3 factors.

Moreover, due to the fact that data reduction is the primary concern, the condensed factors are extracted using the Principal Components Analysis.

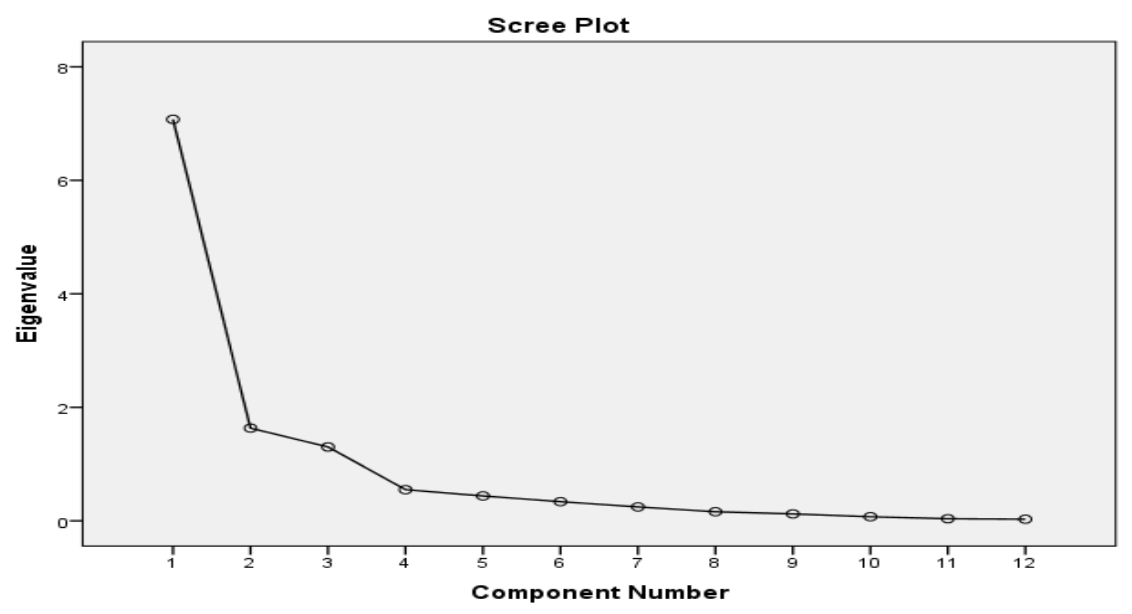

Figure 1. Scree Plot 
Once Factor Rotation is applied, the factor loadings take place and the three condensed factors are identified along with their component parts, as shown in the pattern matrix in Table 3 below.

Table 3. Pattern Matrix

\begin{tabular}{cccc}
\hline Factor & F1 & F2 & F3 \\
\hline Bureaucracy Quality & .991 & -.042 & -.113 \\
Corruption & -.113 & -.900 & -.203 \\
Democratic Accountability & .605 & .344 & .261 \\
Ethnic Tensions & -.967 & -.076 & .027 \\
External Conflict & -.009 & .757 & .318 \\
Government Stability & .187 & -.111 & .787 \\
Internal Conflict & -.868 & -.034 & .187 \\
Investment Profile & -.411 & -.209 & .710 \\
Law \& Order & .824 & -.006 & .181 \\
Military in Politics & .106 & -.118 & -.891 \\
Religious Tensions & -.983 & -.059 & .094 \\
Socioeconomic Conditions & .061 & -.429 & .559 \\
\hline
\end{tabular}

Extraction Method: Principal Component Analysis. Rotation Method: Promax with Kaiser Normalization.

Table 3 distributes the political risk indicators over three factors. By inspecting the factor loadings, "Bureaucracy Quality", "Democratic Accountability", "Law and Order", "Religious Tension", "Internal Conflict" and "Ethnic Tensions" belong to the first factor, $\mathrm{F}_{1}$. All six variables are related directly or indirectly to "Cohesion". As a result, $\mathrm{F}_{1}$ refers to "Cohesion".

The second factor includes "Corruption" and "External Conflict", and these two indicators mostly represent the "Quality of Institutions". Well-functioning institutions curb corruption and resolve external conflicts peacefully. As such, the index " $F_{2}$ " combining "Corruption" and "External Conflict" is referred to as "Quality of Institutions".

The third factor includes "Government Stability", "Military in Politics", "Investment Profile", and "Socioeconomic Conditions" which mostly represent "Governance". Accordingly, $F_{3}$ refers to the "Governance".

Table 4 illustrates the categorization of the factors along with their component variables based on the Principal Components Factor Analysis results.

Table 4. Factor Names and their Component Variables

\begin{tabular}{ccc}
\hline Factor 1: Cohesion & Factor 2: Quality of Institutions & Factor 3: Governance \\
\hline Bureaucracy Quality & & Government Stability \\
Democratic Accountability & Corruption & Investment Profile \\
Ethnic Tensions & External Conflict & Military in Politics \\
Law and Order & & Socioeconomic Conditions \\
Internal Conflicts & & \\
Religious Tensions & & \\
\hline
\end{tabular}

After categorizing the 12 political risk indicators into the three relevant factors, OLS is used to study the relationship between political risk and FDI inflows, while controlling for the other traditional determinants of FDI.

Table 5. Regression Equation

\begin{tabular}{ccccc}
\hline Variables & $\mathrm{R}^{2}$ & $\mathrm{R}^{2}$ adjusted & Unstandardized Beta & $\mathrm{P}$ value \\
\hline Constant & & -3661.85 & 0.027 \\
COHESION & & 299 & 0.044 \\
QUALITY OF INST & & 139.7 & 0.036 \\
GOVERNANCE & & & 180.6 & 0.019 \\
TRADE OPENNESS & 0.441 & 0.314 & -44.15 & 0.96 \\
\hline
\end{tabular}




$\begin{array}{ccc}\text { INFRASTRUCTURE } & -13.8 & 0.664 \\ \text { INFLATION RATE } & 15.39 & 0.283 \\ \text { GROWTH } & 1361.46 & 0.027 \\ \text { LABOR COST } & 0.001 & .324\end{array}$

Table 5 shows the estimated regression coefficients of the determinants of FDI. The estimated coefficients of all three political risk factors are positive, as expected, and statistically significant. In particular, as "cohesion" index increases by one unit, FDI inflows increase by 299 million USD; as the "quality of institutions" index increases by 1 unit, FDI increases by 139.7 million USD and as "governance" index increases by one unit, FDI inflows increases by 180.6 million USD. Political stability stands out as the most important determinant of FDI inflows. Investors hesitate to invest in a Lebanon as long as it suffers from external and internal conflicts, corruption and ethnic tensions. The key to attract FDI is to provide a stable environment that investors can trust.

\section{Conclusion and Recommendation}

This study takes a step forward over the literature on FDI determinants in developing countries, and specifically in Lebanon, by examining 12 ICRG political risk indicators after removing multicollinearity and then grouping the variables into three categories. The regression reveals that "Cohesion", "Quality of Institutions", and "Governance" are all meaningful and significant factors that affect FDI inflows in Lebanon. So, political stability, in general, is considered to be one of the most important determinants of FDI. First and foremost, investors seek countries with fewer conflicts that strictly apply the rules of law and have few bureaucratic complications. This finding is particularly important for the Lebanese stagnant economy that needs foreign investment to stimulate economic growth and create job opportunities.

\section{References}

Abdul Malik, N., \& Masih, M. (2017). Impact of Political Instability on Foreign Direct Investment and Economic Growth: Evidence from Malaysia. MPRA Paper 79418, University Library of Munich, Germany. Retrieved from https://mpra.ub.uni-muenchen.de/79418

Al-Khouri, R., \& Abdul Khalik, M. U. (2013). Does Political Risk Affect the Flow of Foreign Direct Investment into the Middle East North African Region? Journal of Global Business and Technology, 9(2), 47-59.

Asif, M., Yasir, M., \& Chaudhry, A. (2018). Fluctuations in Political Risk Indicators their Impact on FDI Inflow in Pakistan. Asian Journal of Technology Innovation: 1-22. https://doi.org/10.1080/19761597.2018.1547115

Blanton, R., \& Blanton, S. (2007). What Attracts Foreign Investors? An Examination of Human Rights and Foreign Direct Investment. The Journal of Politics, 69(1), 143-155. https://doi.org/10.1111/j.1468-2508.2007.00500.x

Busse, M., \& Hefeker, C. (2007). Political Risk, Institutions, and Foreign Direct Investment. European Journal of Political Economy, 23(2), 397-415. https://doi.org/10.1016/j.ejpoleco.2006.02.003

Dreher, A., \& Gassebener, H. (2005). Greasing the Wheels? The Impact of regulations and Corruption on Firm Entry. Public Choice, 155(3-4), 413-432.

Egger, P., \& Winner, H. (2005). Evidence on Corruption as an Incentive for Foreign Direct Investment. European Journal of Political Economy, 21(4), 932-952. https://doi.org/10.1016/j.ejpoleco.2005.01.002

Gutirrez, K. P. (2015). The Effect of Corruption on FDI in Argentina: Has Corruption Acted as a Negative Determinant Discouraging FDI? Retrieved from Universitat Autonoma de Barcelone.Facultatd'Economia.Empressa: https://ddd.uab.cat/pub/tfg/2015/136831/TFG_kplagutierrez.pdf

Harms, P., \& Ursprung, H. (2002). Do Civil and Political Repression Really Boost Foreign Direct Investments? Economic Enquiry, 40(4), 651-663. https://doi.org/10.1093/ei/40.4.651

Hayakawa, K., Kimura, F., \& Lee, H-H. (2012). How Does Country Risk Matter for Foreign Direct Investment? ERIA discussion paper No. 281. https://doi.org/10.1111/deve.12002

Howell, L. D. (2001). The Handbook of Country and Political Risk Analysis (3rd ed.). The PRS Group: East Syracuse, NY.

Husain, I. (2009). The Role of Politics in Pakistan's Economy. Journal of International Affairs, 63(1), 1-18. Retrieved from https://www.jstor.org/stable/24384169

Kurecic, P., \& Kokotovic, F. (2017). The relevance of Political Stability on FDI: A VAR Analysis and ARDL 
Models for Selected Small, Developed and Instabililty Threatened Economies. Economies, 5(22), 1-21. Retrieved from https://www.mdpi.com/2227-7099/5/3/22/pdf

Lee, H.-H., \& Rajan, R. S. (2011). Cross-border Investment Linkages among APEC Economies: The Case of Foreign Direct Investment. Journal of Korea Trade, 15(3), 89-123. Retrieved from https://ssrn.com/abstract=1946118

Omodero, C. O. (2019). Effect of Corruption on Foreign Direct Investment Inflows in Nigeria. Studia Universitatis Economic Series, 9(2), 54-66. https://doi.org/10.2478/sues-2019-0008

Rogmans, T., \& Ebbers, H. (2013). The Determinants of Foreign Direct Investment in the Middle East North Africa Region. International Journal of Emerging Markets, 8(3), $240-257$. https://doi.org/10.1108/17468801311330310

Root, F. R. (1994). Entry Strategies for International Markets (2nd ed.). Josey-Bass: San Francisco, CA.

Sekkat, K., \& Veganzones-Varoudakis, M. (2007). Openness, Investment Climate, and FDI in Developing Countries. Review of Development https://doi.org/10.1111/j.1467-9361.2007.00426.x

Shahzad, A., Mithani, D. A., Al-Swidi, A. K., \& Bt Fadzil, F. H. (2012). Political Stability and the Foreign Direct Investment Inflows in Pakistan. British Journal of Arts and Social Sciences, 9(2), 199-213.

Slangen, A. H. L., \& Beugelsdijk, S. (2010). The impact of Institutional Hazards on Foreign Multinational Activity: A Contingency Approach Perspective. Journal of International Business Studies, 41(1), 1-16. https://doi.org/10.1057/jibs.2010.1

Sobia, N. (2015). Political Instability and Foreign Direct Investment: Empirical Evidence from Pakistan. European Journal of Business and Management, 7(17), 189-199.

Sparks, R. J., Desai, N., \& Thirumurthy, P. (2014). An Examination of the Country Liquidity Index to Predict a Country's Foreign Direct Investment. International Business \& Economics Research Journal, 13(2), 359-370.

United Nations Conference on Trade and Development. (2019). World Investment Report 2019. United Nations.

\section{Copyrights}

Copyright for this article is retained by the author(s), with first publication rights granted to the journal.

This is an open-access article distributed under the terms and conditions of the Creative Commons Attribution license (http://creativecommons.org/licenses/by/4.0/). 